\title{
Will environmental revegetation increase the threat wildfire poses to assets?
}

\author{
$\underline{\text { L. Collins }}^{\text {a }}$, T.D. Penman ${ }^{\text {a }}$, O.F. Price ${ }^{a}$ and R.A. Bradstock ${ }^{a}$ \\ ${ }^{a}$ Centre for Environmental Risk Management of Bushfires, Institute of Conservation Biology and \\ Environmental Management, University of Wollongong, Wollongong, New South Wales, 2522 \\ Email:lcollins@uow.edu.au
}

\begin{abstract}
Active and passive revegetation is dramatically altering vegetation characteristics across agricultural landscapes globally. There is concern within communities that increased fuel loads associated with revegetation will increase the threat wildfire poses to assets (i.e. life and property). However, the validity and generality of these concerns has not been examined and therefore requires scrutiny. Inherent difficulties associated with the experimental manipulation of fire and the detailed documentation of fire behavior during wildfire events necessitate the need for simulation modeling to address this complex environmental issue. The PHOENIX fire characterisation model was utilised to investigate how the presence and size of revegetation plantings and their proximity to assets (i.e. buildings) influence 'wildfire risk' within a cleared pasture landscape. Elements of 'wildfire risk' examined included (i) the likelihood that fire would reach an asset, (ii) the intensity of fires at an asset and (iii) ember density at an asset. One hundred plantings $990 \mathrm{~m}$ long were established within an agricultural matrix and six 'assets' were located within and at set distances from each planting relative to the fire line ignition (in front of the planting, within the planting and $90 \mathrm{~m}, 270 \mathrm{~m}, 540 \mathrm{~m}$ and $990 \mathrm{~m}$ behind the planting). The width of plantings was varied across simulations (no planting, $90 \mathrm{~m}, 270 \mathrm{~m}, 540 \mathrm{~m}$ and $990 \mathrm{~m})$. Fires were simulated under a range of fire weather $(25$ weather streams) and pasture biomass $\left(2\right.$ tha $^{-1}, 4.5$ tha $^{-1}$ and 7 tha $\left.^{-1}\right)$ conditions. This resulted in 375 simulation runs with 600 assets being sampled in each simulation (i.e. 225000 data points in total). The inclusion of plantings did not increase the likelihood of fire reaching an asset, with large plantings (i.e. $540 \mathrm{~m}$ and $990 \mathrm{~m}$ wide) actually reducing the likelihood under certain conditions (i.e. low pasture fuel loads, moderate weather conditions). The intensity of fires within the pasture matrix was dependent upon pasture biomass and weather conditions, not the presence or size of plantings. The addition of plantings did increase the risk of embers reaching an asset. However, the density of embers was generally low (i.e. $<10$ embers/ha) at sampling locations that were not directly adjacent to the planting (i.e. $\geq 270 \mathrm{~m}$ ). In general, weather and pasture biomass had a greater influence on 'wildfire risk' than plantings. These results suggest plantings are likely to have little impact on the threat wildfire poses to built assets and that wildfire risk will be more strongly determined by fire weather and pasture management. The approach used in our study provides a useful method to quantitatively assess the relative effect environmental plantings will have on the risk fire poses to built assets under a range of environmental conditions.
\end{abstract}

Keywords: PHOENIX rapidfire, fire risk, revegetation 


\section{INTRODUCTION}

Active and passive revegetation is occurring across agricultural landscapes globally (Kyle and Duncan, 2012; Moreira et al., 2001; Rudel et al., 2005), resulting in dramatic changes to vegetation characteristics and fuel structure and connectivity (Moreira et al., 2001; Rey Benayas et al., 2007; Romero-Calcerrada and Perry, 2002). The conversion of pasture or grassland to shrubland, woodland or forest will increase fuel biomass at a point in the landscape (Moreira et al., 2001; Sullivan et al., 2012). Several fire behavior models predict that increased fine fuel biomass will result in greater fire intensity and/or rate of spread, and thus a reduced likelihood of fire suppression (Gill et al., 1987; Noble et al., 1980). Consequently, concern exists that increased connectivity of vegetation with 'high' fuel biomass at the expense of agricultural grassland will result in greater fire occurrence and more intense fires, and ultimately an elevated fire risk posed to life and property (Moreira et al., 2001; Rey Benayas et al., 2007; Romero-Calcerrada and Perry, 2002). However, the validity and generality of these concerns has not been extensively examined and therefore requires scrutiny.

There is inherent difficulty in assessing landscape scale questions related to fire behavior and its response to landscape change. Field based experiments examining the effect of revegetation on fire risk to assets is problematic for public safety reason as is data collection during wildfire events. Simulation modeling provides a useful alternative, as it can be used to conduct replicated landscape scale experiments that can provide insight into the impact management decisions may have on fire behavior and the threat posed to assets (e.g. Bar Massada et al., 2009; Duguy et al., 2011).

The aim of this paper was to examine whether revegetation within agricultural landscapes will lead to changes in the exposure of built assets (i.e. houses) to fire. The PHOENIX fire characterization model (hereafter 'PHOENIX') was utilized to simulate fire behavior. Specifically we set out to examine whether the presence and characteristics (i.e. size and proximity to assets) of plantings effect (i) the probability of fire reaching an asset, (ii) the intensity of fires that reach an asset and (iii) the density of embers that reach an asset.

\section{METHODS}

\subsection{Study area}

The study took place within a predominantly agricultural landscape west of Sydney, south eastern Australia (Figure 1a). This region was selected as it has been highly modified by agricultural activities and covers a range of topographic conditions over which revegetation is likely to occur.

\subsection{PHOENIX}

A brief description of models and input data used by PHOENIX is provided below. More detailed descriptions are provided in Tolhurst et al. (2008) and Saeedian et al. (2010).

The PHOENIX fire simulation model is dynamic in nature as simulated fire behavior will respond to changes in environmental conditions and the conditions of the fire (Tolhurst et al., 2008). Surface fire behavior, which includes flame height, fire intensity and ember density, is simulated using the CSIRO southern grassland fire spread model (Cheney et al., 1998) and a modified version of the McArthur Mk5 forest fire

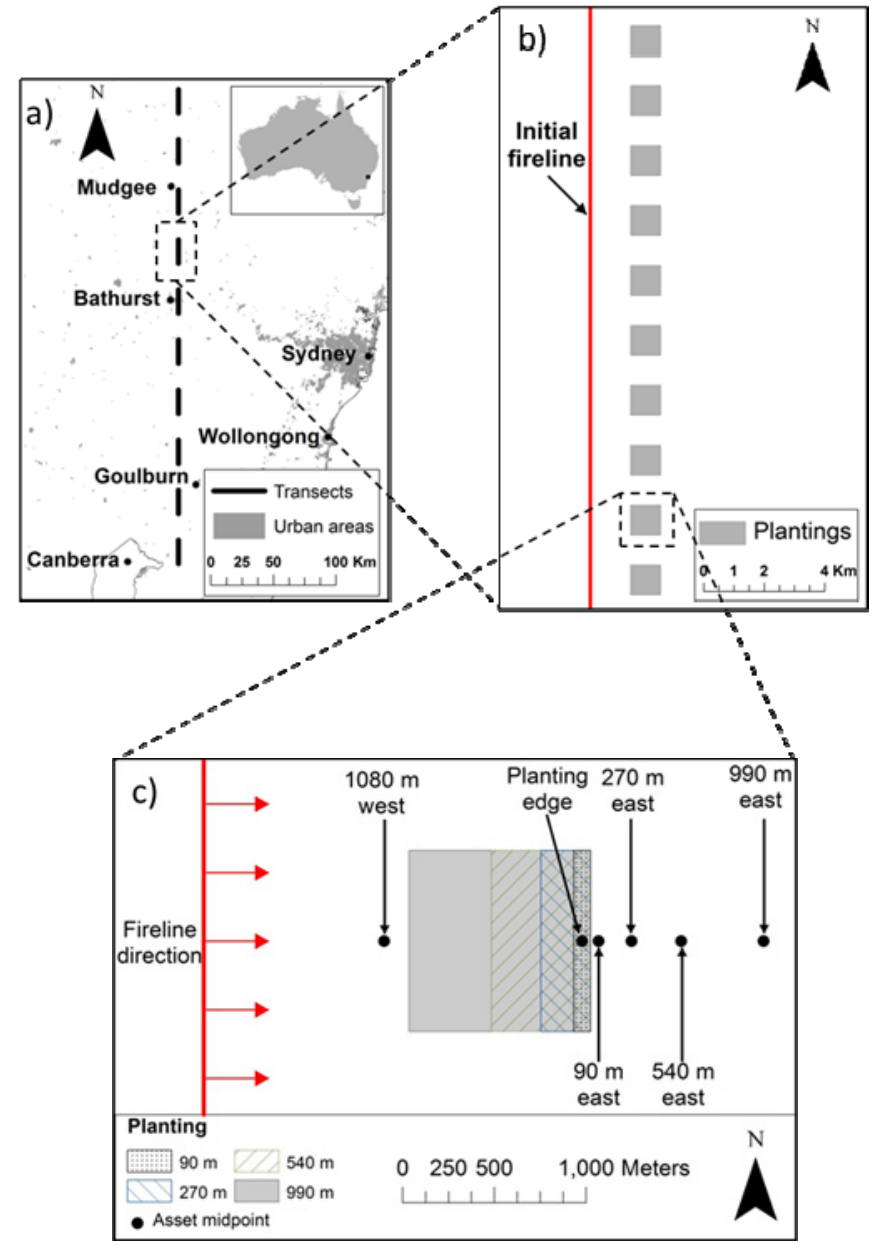

Figure 1 (a) Location of transects across the study region, (b) configuration of plantings along a single transect and (c) location of assets relative to a single planting. 
behavior model (Noble et al., 1980), while the spatial propagation of fire is simulated using Huygen's algorithm (Tolhurst et al., 2008). PHOENIX utilizes a number of input environmental variables for fire simulation, including grid layers $(30 \mathrm{~m}$ resolution) of topography, fuel type, time since fire and fuel disruptions (e.g. roads, waterbodies). User defined fuel accumulation curves, which specify fuel biomass for each vegetation community as a function of time since fire, are used by PHOENIX to estimate fuel biomass from grid layers of fuel type and time since fire. A range of weather parameters are input as a series of time steps by the user for both pre-fire fuel conditioning and fire behavior. The spatial resolution of simulation output is specified by the user, and for our study this was set at a grid cell resolution of $90 \mathrm{~m}$.

\subsection{Simulation design}

Ten replicate $\sim 20 \mathrm{~km}$ transects with $\sim 20 \mathrm{~km}$ spacing were set up in a north-south orientation along a single $\mathrm{N}-\mathrm{S}$ line extending from Canberra to $\sim 100 \mathrm{~km}$ north of Mudgee (Figure 1a). Ten simulated $990 \mathrm{~m}$ long plantings spaced $990 \mathrm{~m}$ apart were created along each transect (Figure 1b). The effect of five different planting widths were simulated, namely $0 \mathrm{~m}$ (i.e. no planting), $90 \mathrm{~m}$ ( 1 output cell), $270 \mathrm{~m}$ ( 3 cells), 540 (6 cells) and $990 \mathrm{~m}$ (11 cells) (Figure 1c). The eastern edge of the plantings was consistent across all the different planting widths (Figure 1c). Strategically located cells within the simulation landscape were nominated as built 'assets'. Assets were placed at $0 \mathrm{~m}, 180 \mathrm{~m}, 270 \mathrm{~m}, 540 \mathrm{~m}$ and $900 \mathrm{~m}$ from the planting, with the spacing determined by the number of grid cells east of the eastern edge of the plantings. The different asset locations are identified throughout the remainder of the paper using the location of the eastern edge of the $90 \mathrm{~m}$ cell (Figure 1c). A single N-S fire line was ignited approximately $2000 \mathrm{~m}$ from the eastern edge of the plantings (Figure 1b). A control point was located between the fire line ignition and the planting, $1080 \mathrm{~m}$ west of the eastern edge of the planting, to determine the extent to which burn probability, intensity and ember load changed as a result of the planting (Figure 1c). Vegetation surrounding the plantings was defined as pasture, with three fuel loads $\left(2 \mathrm{tha}^{-1}, 4.5 \mathrm{tha}^{-1}\right.$ and $\left.7 \mathrm{tha}^{-1}\right)$ tested, representing years of low rainfall or pastures that have been grazed or mown (i.e. 2 tha $^{-1}$ ), average rainfall and low or no grazing (i.e. 4.5 tha $^{-1}$ ) and high rainfall and low or no grazing $\left(7 \mathrm{tha}^{-1}\right)$ (Gill et al., 2010, Cheney and Sullivan, 2008). Fuels within pastures may attain maximum biomass within 12 months (Sullivan et al., 2012), so we assumed that maximum biomass in pasture was attained immediately post fire (i.e. by 1 year post fire). Disruptions (e.g. urban areas, roads, rivers, lakes) were removed from the landscape and fire history was set at 50 years since fire for the entire landscape. All plantings were classified as mature dry sclerophyll forest with a shrubby understorey, as this community has the highest fuel load of the vegetation communities predominantly used for replanting (i.e. grassy woodland and dry sclerophyll forest), and therefore represents the worst case scenario. Ten kilometer wide fuel breaks were placed between transects, and at least $5000 \mathrm{~m}$ from the plantings, to ensure that the 10 fires burnt independently of each other.

\subsection{Simulation specification and base data}

Wildfire characteristics (e.g. fire size, intensity, ember loads) are strongly determined by fire weather (Bradstock et al., 2009; Bradstock et al., 2010; Luke and McArthur, 1978). In Australia the severity of fire weather in grassland dominated ecosystems is commonly measured using the grassland fire danger index (GFDI) (Gill et al., 1987). We used 25 weather streams that occurred during actual wildfire events within the Sydney bioregion spanning a range of GFDI conditions (Moderate - extreme). Hourly weather observations taken over a 24 hour period were provided from the Australian Bureau of Meteorology, with each weather stream commencing at $\sim 0000 \mathrm{hrs}$ and concluding at $2330 \mathrm{hrs}$. Data were taken from stations of Richmond, Sydney Airport, Cessnock and Moss Vale. Wind direction for all weather streams was modified to remain constant at $270^{\circ}$ so that fires would burn towards the plantings and assets. Fire lines were ignited at $1400 \mathrm{hrs,}$ when fire weather will generally peak due to typical diurnal fluctuations in wind speed, temperature and relative humidity (Sullivan et al., 2012). GFDI was calculated at 1400 hrs for each weather stream using equations for the grassland fire danger meter Mark 3 (Noble et al., 1980).

The degree of grass curing (i.e. percentage of material within a grass sward that is dead; Cheney and Sullivan, 2008) was set at $100 \%$ for the simulations, as observations and simulations of grass growth and death near Canberra suggest that grass curing will generally approach 100\% during the summer months (Gill et al., 2010; Luke and McArthur, 1978), which coincides with the fire season across the study area (Luke and McArthur, 1978).

Base grid data layers (e.g. digital elevation models, vegetation maps, fire history) used in the simulations were provided by the NSW Rural Fire Service. 


\subsection{Analysis}

Analysis focused on three response variables, namely whether an asset was exposed, the intensity of fire at assets and the density of embers at assets. Generalized linear mixed models (GLMMs) were used to assess the influence of the predictor variables on the probability of an asset burning. Generalized additive mixed models (GAMMs) were used to assess the influence of the predictor variables on ember density and fire intensity experienced at an asset. GAMMs were used as the influence of GFDI and topographic variables on fire intensity and ember density were not expected to be linear. The number of knots in the GAMMs was restricted to three to avoid over-fitting the data. Transects (Figure 1a) were specified as a random factor in the GAMMs and GLMMs to account for the nested nature of the experimental design. A random subset of 50000 data points was used for each analysis in order to optimize model fitting, unless fewer data points were available. Akaike's Information Criterion (AIC) was used to identify the key variables that were influencing fire characteristics. AIC provides a measure of model fit while also penalizing model complexity (Akaike, 1973). A range of predictor variables were considered in the analysis, including asset location, planting width, pasture fuels, GFDI, slope, topographic position and aspect. Two-way interactions were tested between (i) asset location and planting width, (ii) aspect and slope and (iii) aspect and topographic position. The topographic interactions were assessed as the effect of slope and topographic position should be dependent on head fire direction (Luke and McArthur, 1978). Every possible combination of the variables and interactions listed above were assessed using AIC, though results relating to topographic effects will not be discussed in detail in this paper. Models with the lowest AIC are considered to have the best fit and models within 2 AIC points are plausible alternatives, (Quinn and Keough, 2002). GLMMs and GAMMs were performed using the 'Ime4' and 'mgcv' packages respectively in R (R Development Core Team, 2010).

\section{RESULTS}

\subsection{Probability of fire reaching an asset}

The probability of fire reaching an asset was strongly dependent upon fire weather, whereby fire reached almost all (i.e. $>97 \%$ ) of the assets if weather exceeded moderate GFDI (>7.5). Consequently, analysis of the influence of planting size and asset location was restricted to fires burning under moderate GFDI. Pasture fuel load, and interactions between planting width and asset location, slope and aspect and topographic position and aspect were included in the best model. Increased planting width reduced the probability of fire reaching an asset (Figure 2). The probability of fire reaching an asset decreased with increasing distance from the edge of a planting (Figure 2), though this effect was only significant when the $540 \mathrm{~m}$ and $990 \mathrm{~m}$ wide plantings were present. Furthermore, distance from planting appeared to be more influential in reducing the probability of burning when pasture biomass was 'low' (Figure 2). Assets were also less likely to be exposed when there was 'low' pasture biomass (i.e. 2 tha $^{-1}$ ) in the surrounding matrix (Figure 2).

\subsection{Fire intensity}

The influence of asset location on fire intensity varied with pasture biomass, therefore analysis was conducted separately within each pasture level. GFDI and interactions between planting width and asset location, slope and aspect and topographic position and aspect were included in the fire intensity models for each of the different pasture levels (Figure 3). Increased fuel loads within the pasture matrix led to an increase in fire intensity, though intensity within plantings (i.e. Asset location = Planting) remained at relatively consistent levels across all pasture fuel levels (Figure 3a-c). Consequently, fire intensity within 
plantings was (i) higher relative to fire intensity within pastures of 'low' fuel (Figure 3a), (ii) similar to fire intensity within pastures of 'moderate' fuel (Figure 3b) and (iii) lower relative to fire intensity within pastures of 'high' fuel (Figure 3c). Fire intensity returned to baseline values (i.e. fire intensity when there is no planting present) when the fire left the planting and re-entered pasture. Fire intensity increased with increasing GFDI in both pasture and plantings (i.e. $\sim 4-6$ fold increase when GFDI increased from 0 - 100). Within pasture the magnitude of change in intensity in response to GFDI increased with increasing pasture biomass.

\subsection{Asset exposure to embers}

None of the assets were predicted to be affected by embers in simulations where plantings were absent or if the assets were located west of the planting, which reflects the lack of spotting in the grassfire models used by PHOENIX (see Discussion). Furthermore, embers were not predicted within the $90 \mathrm{~m}$ wide plantings. Consequently, data from these simulations were not used in the modeling process.

Pasture fuel load, GFDI, slope, aspect and
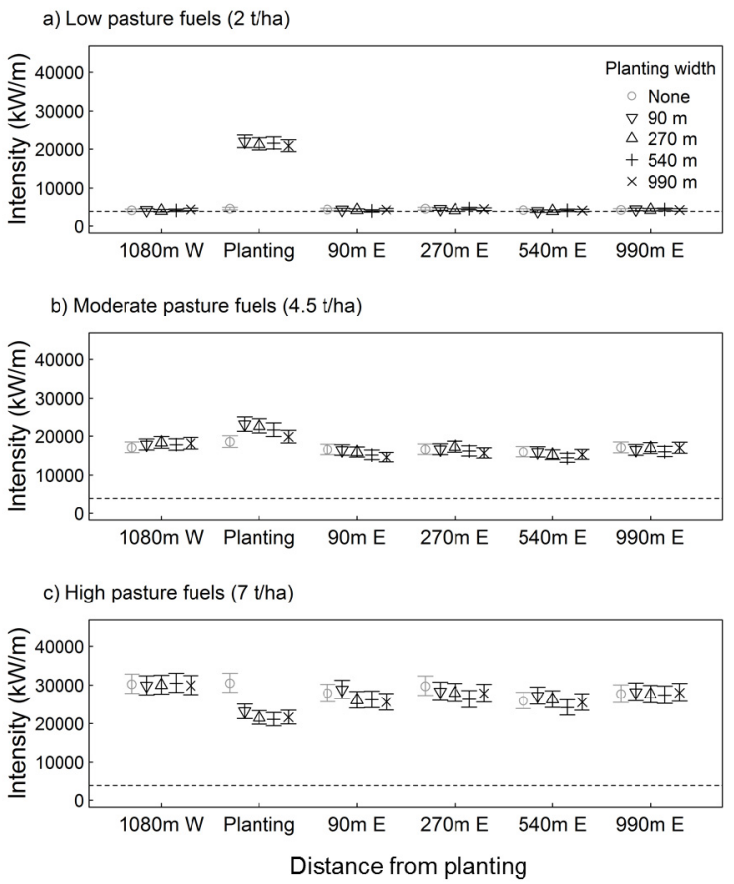

Figure 3 The predicted influence of planting width and distance from planting on fire intensity under conditions of (a) low, (b) moderate and (c) high pasture biomass.

Error bars show $95 \%$ confidence intervals. Model parameters were held constant as follows: GFDI $=32$, slope $=7^{\circ}$, topographic position $=67$ and aspect $=$ west. interactions between planting width and asset location and topographic position and aspect were included in the selected ember density model. Ember density was greatest at assets located within plantings and $90 \mathrm{~m}$ east of plantings (Figure 4). The number of embers (mean \pm s.d.) was generally low for assets located $270 \mathrm{~m}$ (e.g. $10.36 \pm 10.21$ embers/ha), $540 \mathrm{~m}$ (e.g. $3.11 \pm 3.88 \mathrm{embers} / \mathrm{ha}$ ) and $990 \mathrm{~m}$ (e.g. $1.05 \pm 1.67 \mathrm{embers} / \mathrm{ha}$ ) east of the plantings (Figure 4), regardless of planting width. Ember density increased with GFDI, though density generally remained low at assets located far (i.e. $>270 \mathrm{~m}$ ) from plantings regardless of GFDI.

\section{DISCUSSION AND CONCLUSIONS}

Our findings suggest that environmental revegetation will alter the exposure of built assets (i.e. houses) to fire, though increased fuel biomass associated with revegetation did not unequivocally lead to an increased fire risk. Larger plantings (e.g. 540 - $990 \mathrm{~m}$ wide) were found to decrease fire exposure under moderate weather conditions by reducing the probability of a fire reaching an asset, provided that the pasture between the asset and a planting is in a state of low biomass (i.e. 2 tha $^{-1}$ ). On the other hand, plantings alter exposure by facilitating ember production, though the level of risk (i.e. ember density) declined rapidly as the distance between plantings and assets increased. Interestingly, our results suggest that fire weather and pasture biomass management will be far more influential than the occurrence or arrangement of plantings in determining the exposure of assets.

The characteristics of grass fuels (i.e. high surface area to volume ratio, vertical orientation, rapid drying, low wind reduction) generally make them more flammable (i.e. less energy required for combustion) than forest litter, and thus capable of supporting rapidly spreading fires (Sullivan et al., 2012). Situations may arise whereby patches of remnant forest within a pasture matrix slow the rate of fire spread (e.g. low - high FFDI), providing suppression opportunities for fire crews. The lower flammability of forest fuels and wind reduction associated with trees will result in an increased likelihood of fires self-extinguishing, which explains why under moderate GFDI the likelihood of a fire reaching an asset was reduced when plantings were located upwind. Therefore, strategic placement of plantings may aid fire suppression in certain situations.

The effect of plantings on fire intensity and ember density within agricultural landscapes appeared to be highly localized. Fire intensity was only noticeably altered by the presence of plantings within the bounds of a planting (i.e. plantings had no effect on intensity in the surrounding matrix). This is because the amount of fuel available to burn at a point in the landscape will limit fire intensity (Luke and McArthur, 1978). In situations where pasture biomass is 'low', flames and radiant heat produced by the planting may contribute to 
the ignition of flammable structures, though risk will be confined to those structures close (i.e. $<100 \mathrm{~m}$ ) to the planting (Cohen, 2000; Standards Australia, 2011). Ember density increased when plantings were included in the pasture matrix, though ember density rapidly decreased with distance from the planting, which is consistent with observed patterns (Koo et al., 2010; Luke and McArthur, 1978). Under average weather and topographic conditions, ember density was $\sim 10-30$ embers $\mathrm{ha}^{-1}$ adjacent to plantings $(0-90 \mathrm{~m})$, decreasing to below $\sim 5$ embers ha $^{-1}$ between 180 $\mathrm{m}$ and $990 \mathrm{~m}$ from the planting. This finding is consistent with the Australia Standards, which suggest ember attack will only pose a sufficient risk up to $100 \mathrm{~m}$ from forest vegetation (Standards Australia, 2011). There were no embers observed in the baseline pasture simulations (i.e. when no plantings were present), which merely reflects that the grassfire model used in PHOENIX does not contain a spotting component. Embers arising from thistle heads or grass seed heads may be quite common within $100 \mathrm{~m}$ of a grassfire front (Luke and McArthur, 1978). Hence, there will be a risk of ember attack from grassfires, though this risk will only be elevated over short distances (e.g. within $50 \mathrm{~m}$ ) (Standards Australia, 2011).

The simulation modeling approach used in our study provides a useful method to quantitatively assess the effect environmental plantings will have on the fire exposure to built assets. Conducting manipulative fire experiments of this nature is impossible due to safety reasons, difficulty in finding meaningful revegetation replicates and the large number of factorial combinations of weather, pasture biomass and planting characteristics (i.e. width and distance) that would be required. Identification of key relationships and issues associated with plantings and fire risk using PHOENIX will allow for the development of meaningful management guidelines and priority research areas of experimentation for scientists.

\section{ACKNOWLEDGEMENTS}

This project was supported by the Hawkesbury-Nepean Catchment Management Authority (HNCMA), through funding from the Australian Government's Caring for our Country. We would like to thank Robert Adam, Bill Dixon and Aaron Smith from the HNCMA for their support and advice. This paper has been modified from a report provided to the HNCMA.

\section{REFERENCES}

Akaike, H. (1973). Information theory as an extension of the maximum likelihood principle. Paper presented at Proceedings of the Second International Symposium on Information Theory, Budapest,

Bar Massada, A., Radeloff, V.C., Stewart, S.I. and Hawbaker, T.J. (2009). Wildfire risk in the wildlandurban interface: A simulation study in northwestern Wisconsin. Forest Ecology and Management, 258(9), 1990-1999.

Bradstock, R.A., Cohn, J.S., Gill, A.M., Bedward, M. and Lucas, C. (2009). Prediction of the probability of large fires in the Sydney region of south-eastern Australia using fire weather. International Journal of Wildland Fire, 18(8), 932-943.

Bradstock, R.A., Hammill, K.A., Collins, L. and Price, O. (2010). Effects of weather, fuel and terrain on fire severity in topographically diverse landscapes of south-eastern Australia. Landscape Ecology, 25(4), 607619. 
Collins et al., Will environmental revegetation increase the threat wildfire poses to assets?

Cheney, N.P., Gould, J.S. and Catchpole, W.R. (1998). Prediction of fire spread in grasslands. International Journal of Wildland Fire, 8(1), 1-13.

Cheney, P. and Sullivan, A. (2008). Grassfires: Fuel, weather and fire behaviour. CSIRO Publishing, Collingwood.

Cohen, J.D. (2000). Preventing disaster: Home ignitability in the wildland-urban interface. Journal of Forestry, 98(3), 15-21.

Duguy, B., Alloza, J.A., Röder, A., Vallejo, R. and Pastor, F. (2011). Modelling the effects of landscape fuel treatments on fire growth and behaviour in a Mediterranean landscape (eastern Spain). International Journal of Wildland Fire, 16(5), 619-632.

Gill, A.M., Christian, K.R., Moore, P.H.R. and Forrester, R.I. (1987). Bushfire incidence, fire hazard and fuel reduction burning. Australian Journal of Ecology, 12(3), 299-306.

Gill, A.M., King, K.J. and Moore, A.D. (2010). Australian grassland fire danger using inputs from the GRAZPLAN grassland simulation model. International Journal of Wildland Fire, 19(3), 338-345.

Koo, E., Pagni, P.J., Weise, D.R. and Woycheese, J.P. (2010). Firebrands and spotting ignition in large-scale fires. International Journal of Wildland Fire, 19(7), 818-843.

Kyle, G. and Duncan, D.H. (2012). Arresting the rate of land clearing: Change in woody native vegetation cover in a changing agricultural landscape. Landscape and Urban Planning, 106(2), 165-173.

Luke, R.H. and Mcarthur, A.G. (1978). Bushfires in Australia. Department of Primary Industries, Forestry and Timber Bureau, CSIRO Division of Forest Research, AGPS, Canberra.

Moreira, F., Rego, F.C. and Ferreira, P.G. (2001). Temporal (1958-1995) pattern of change in a cultural landscape of northwestern Portugal: implications for fire occurrence. Landscape Ecology, 16(6), 557-567.

Noble, I.R., Bary, G.A.V. and Gill, A.M. (1980). McArthur's fire-danger meters expressed as equations. Australian Journal of Ecology, 5(2), 201-203.

Quinn, G.P. and Keough, M.J. (2002). Experimental Design and Data Analysis for Biologists. Cambridge University Press, Cambridge.

R Development Core Team (2010). R: A language and environment for statistical computing. R Foundation for Statistical Computing, Vienna, Austria.

Rey Benayas, J.M., Martins, A., Nicolau, J.M. and Schulz, J.J. (2007). Abandonment of agricultural land: an overview of drivers and consequences. CAB Reviews: Perspectives in Agriculture, Veterinary Science, Nutrition and Natural Resources, 2(57), 1-14.

Romero-Calcerrada, R. and Perry, G.L.W. (2002). Landscape change pattern (1984-1999) and implications for fire incidence in the SPA Encinares del rio Alberche y Cofio (Central Spain). Paper presented at Forest Fire Research and Wildland Safety. Proceedings of the IVth International Conference on Forest Fire Research, Coimbra, Portugal, 18-23 November 2002.

Rudel, T.K., Coomes, O.T., Moran, E., Achard, F., Angelsen, A., Xu, J. and Lambin, E. (2005). Forest transitions: towards a global understanding of land use change. Global Environmental Change, 15(1), 23-31.

Saeedian, P., Moran, B., Tolhurst, K. and Halgamuge, M.N. (2010). Prediction of high-risk areas in wildland fires. Paper presented at the 5th International Conference on Information and Automation for Sustainability (ICIAFs), 17-19 Dec. 2010, Colombo, Sri Lanka, 17-19 Dec. 2010.

Standards Australia (2011). Australian Standard: Construction of Buildings in Bushfire Prone Areas. Standards Australia, Sydney NSW.

Sullivan, A.L., McCaw, W.L., Cruz, M.G., Matthews, S. and Ellis, P.F. (2012). Fuel, fire weather and fire behaviour in Australian ecosystems. In R.A. Bradstock, A.M. Gill and R.J. Williams. Flammable Australia: Fire Regimes, Biodiversity and Ecosystems in a Changing World. CSIRO Publishing, Collingwood, VIC.

Tolhurst, K., Shields, B. and Chong, D. (2008). PHOENIX: development and application of a bushfire risk management tool. The Australian Journal of Emergency Management, 23(4), 47-54. 